\title{
Case autoimmune pancreatitis in children
}

\author{
Alicia G Cazares Camacho ${ }^{1 *}$, Maria Maldonado ${ }^{1}$, Enrique Faugier ${ }^{1}$, Maria de Lourdes Cabrera ${ }^{2}$ \\ From 21st European Pediatric Rheumatology (PReS) Congress \\ Belgrade, Serbia. 17-21 September 2014
}

\section{Introduction}

Autoimmune pancreatitis represents $2 \%$ of chronic pancreatitis, most often in adult male presentation associated with IgG4. We present a case of a patient 6 years old, with a dependent pancreatic and bile duct obstruction abdominal mass, which is interesting because this presentation in children is more common with autoimmune pancreatitis that malignancies.

\section{Objectives}

Show an exceptional case in pediatrics rheumatology.

\section{Methods}

Presentation of case.

\section{Results}

Female 6 years old, previously healthy, 3-year evolution gastric recurrent vomiting, abdominal pain intermittently mesogastrio, adding hiporexia, jaundice and increased waist circumference, with palpable mass in the right upper quadrant. Cholestatic syndrome, 857 Lipase, amylase 137 Immunoglobulin IgG subclass $4: 23 \mathrm{mg} / \mathrm{dL}$ (5-6 years: 1-121 ). CT: dilatation of intra and extra hepatic bile duct. Level space-occupying hepatic hilum extending to pancreatic head and esophagogastric junction mass. Gonadotropin and alpha-fetoprotein: negatives. Cholecystectomy, incisional biopsy of tumor, liver biopsy was performed. He reported: lymphoplasmacytic sclerosing pancreatitis. (chronic autoimmune pancreatitis).

\section{Conclusion}

This is a rare autoimmune disorder that resembles a pancreatic neoplasm with biliary obstruction, occurring primarily in adults, making it an exceptional case in pediatrics . As part of an IgG4 -associated systemic disease , serum level may be normal in up to $40 \%$, being positive in pancreatic tissue.

'Reumatologia pediatrica, Hospital Infantil de Mexico Federico Gomez, Mexico City, Mexico

Full list of author information is available at the end of the article

\author{
Disclosure of interest \\ None declared
}

Authors' details

${ }^{1}$ Reumatologia pediatrica, Hospital Infantil de Mexico Federico Gomez, Mexico City, Mexico. ${ }^{2}$ Patologia, Hospital Infantil de Mexico Federico Gomez, Mexico City, Mexico.

Published: 17 September 2014
Submit your next manuscript to BioMed Central and take full advantage of:

- Convenient online submission

- Thorough peer review

- No space constraints or color figure charges

- Immediate publication on acceptance

- Inclusion in PubMed, CAS, Scopus and Google Scholar

- Research which is freely available for redistribution
C Biomed Central 